\title{
English Teachers' Perceptions of Technology Integration: Are They Different From Their Peers in Engineering and Medical Science?
}

\author{
Elias Bensalem ${ }^{1}$ \\ ${ }^{1}$ Department of Languages and Translation, Northern Border University, Saudi Arabia \\ Correspondence: Elias Bensalem, Department of Languages and Translation, Northern Border University, Saudi \\ Arabia. E-mail: bensalemelias@gmail.com
}

$\begin{array}{ll}\text { Received: September 20, } 2018 & \text { Accepted: October 11, } 2018 \text { Online Published: December 29, } 2018 \\ \text { doi:10.5539/ijel.v9n1p152 } & \text { URL: https://doi.org/10.5539/ijel.v9n1p152 }\end{array}$

\begin{abstract}
The role played by subject areas in information and communication technology (ICT) integration has been insufficiently researched. This study compares English language teachers' perceptions of ICT integration with their peers in engineering and medical science in ICT integration. It also examines the effects of teachers' sociobiographical variables (gender, age, computer proficiency, and years of teaching experience) predict teachers' perceptions of ICT integration. A total of 180 teachers (112 males, 68 females) responded to a Teacher Technology Questionnaire (Lowther, Inan, Strahl, \& Ross, 2008). Results show that among the predictor variables, computer skills had the highest impact on ICT integration. Furthermore, English language teachers' perceptions of ICT are reported to be similar to those of their peers in engineering and medical science. This study does not lend support to any significant role played by subject area in ICT integration. Implications for teaching are offered.
\end{abstract}

Keywords: English language teachers, technology integration, technology use, computer use in education, subject area

\section{Introduction}

The use of ICT tools in schools and universities started during the 1980s (Sheingold \& Hadley, 1990) and stirred the enthusiasm of teachers and educational policy makers alike. Technology was considered then as a revolutionary pedagogical tool for the future. It was credited for improving student achievement on standardized tests (Cuban, 1993), providing new opportunities for effective communication between teachers and students in ways that have not been possible before. In addition, it allowed students to pursue online courses outside the traditional context of the brick-and-mortar classroom (Sandholtz, Ringstaff, \& Dwyer, 1997). The use of new technologies in the classroom plays a crucial role in preparing students for their personal and professional lives (Chamorro \& Rey, 2013), and also in providing ample opportunities for students to construct their own knowledge, which is conducive to learning (Cuban, 2001). Barron, Orwig, Ivers and Lilavois (2001) have argued that ICT integration have numerous benefits. It encourages students to learn actively and cooperatively and supports various learning styles. Most importantly, it provides individual development and motivation and fosters teacher-student interaction. As many universities in Saudi Arabia are seeking international accreditation ICT integration has become a pressing matter.

The perspective that ICT use in education can have a positive effect student learning has prompted the creation of programs for the integration of technology in schools and universities (Gray, Thomas, \& Lewis 2010; Oxford Business Group, 2010). However, the integration of ICT in education was not a straightforward matter. It has become evident that it is not enough to introduce computers in schools to get a situation where all teachers use ICT in teaching and learning. In fact, belief among a growing number of educators that technology integration in the classroom is also somehow related to subject areas (e.g., Ertmer \& Ottenbreit-Leftwich, 2010; Hew \& Brush, 2007; Howard, Chan, \& Caputi, 2014; Inan \& Lowther, 2010). In other words, certain subject areas tend to integrate technology in teaching more than others. However, not enough research has been conducted to clarify the relationship between subject areas and ICT integration (Howard et al., 2014). The present study is an attempt to fill this lacuna by comparing whether the English language teachers' attitudes towards technology integration are different from their peers in the subject areas of engineering and medical science. 


\section{Literature Review}

\subsection{Subject Area and ICT Integration}

There is growing belief among many researchers that subject areas may influence teachers' decision to get involved or shy away from educational ICT integration in the classroom (e.g., Ertmer \& Ottenbreit-Leftwich, 2010; Hew \& Brush, 2007; Howard et al., 2014; Inan \& Lowther, 2010). In a meta-analysis of 1055 individual studies of ICT, Tamim, Bernard, Borokhovski, Abrami and Schmid (2011) reported that subject areas tend to play a major influence on in technology integration among instructors.

In another study, Howard and Maton (2011) examined technology integration among teachers of mathematics and teachers of English. Results showed a disparity in the use of ICT within their classrooms. Mathematics instructors tended to use ICT less frequently in their teaching than the English language teachers. They argued that the focus of mathematics was to practice in class and that mathematics software applications were not as valuable in achieving learning outcomes. They asserted that students could use such applications as supplementary resources. Conversely, English teachers reported greater integration of ICT in their teaching as they valued the importance of ICT in enhancing students' learning. The divergence of beliefs about the value of integrating ICT in the classroom was reported in a later study where English teachers had greater use of ICT than their peers teaching mathematics (Howard \& Maton, 2013).

In a more recent experiment, Howard et al. (2014) concluded that there is a strong correlation between subject areas they examined (English, mathematics, and science) and technology integration. Specifically, the researchers found science to have the highest frequency of integration followed by English while mathematics had the lowest frequency of ICT integration.

Howard et al. (2014) highlighted that "ultimately, subject areas do matter in technology integration" (p. 8). They argued that the use of particular ICT tools was more relevant with particular subject areas. For example, the use of word processing software was more suitable to use in English while graphic software seemed to be more relevant to mathematics. The researchers reported significant differences between the frequencies of ICT integration among teachers of English, mathematics, and science over the course of three years. Science teachers had the highest frequency of ICT integration, while mathematics teachers had the lowest frequency of ICT integration.

Tay, Lim, and Lim (2015) conducted a study involving elementary school teachers in Singapore by on the relationship between ICT usage and subject area. The subject areas examined by the researchers included English, science, mathematics, and other languages (i.e., Chinese, Malay, and Tamil). Results showed that the rates of ICT integration for these subjects were significantly different. Based on interviews with instructors from the different subjects, English teachers had the highest frequency usage of ICT, followed by mathematics teachers who had a medium usage of ICT. Science teachers and teachers of mother tongue languages had a low usage of ICT. The researchers suggest subject areas may have an effect on ICT usage rates. They argued that ICT was adopted more by English teachers since it helped them incorporate elements of collaboration. Mathematics teachers, however, adopted ICT occasionally, primarily when there was a need for reinforcement tools to provide further opportunities for their students to practice and retain the concepts they learned. Tay et al. (2015) have called for further research on the role played by subject in ICT use.

\subsection{A Model of ICT Integration}

In the present study, the impact of subject areas on teachers' integration of ICT is examined using a modified version of the Inan and Lowther's (2010) model of teachers' technology integration. The adapted model includes factors that help explore the relationship between ICT integration and subject areas. There are four variables. Two are related to the teacher: teacher readiness and teacher beliefs. The other two variables are related to the educational institution: overall support and technical support. Teacher readiness refers to teachers' perceptions of their abilities to integrate ICT into the classroom. Teacher beliefs, however, refer to teachers' perceptions about how ICT may influence both students and classroom instruction.

\subsection{The Present Study}

This study set out to investigate whether the effects of teachers' sociobiographical variables (gender, age, computer proficiency, and years of teaching experience) predict teachers' perception of ICT integration. Furthermore, this study aimed at exploring whether English Teachers' perceptions of technology integration is different from their peers in engineering and medical science through examining the relationship between ICT integration and key factors including: teacher readiness, teacher beliefs, teachers' perceptions of overall support, and technical support. The following two research questions were addressed: 
1. To what extent do sociobiographical variables (gender, age, computer proficiency, and years of teaching experience) predict teachers' perceptions of ICT integration?

2. To what extent are English Teachers' perceptions of technology integration different from their peers in engineering and medical science?

\section{Methods}

\subsection{Participants and Procedure}

Study participants included 180 teachers (112 males, 68 females). The gender difference between males and females was $62 \%$ to $38 \%$, respectively. Most of the participants were aged between 30 and 39 years. They are originally from different countries including India, Egypt, Jordan, Tunisia, and the US. Most of the teachers recruited for this study have over six years of teaching experience. As Table 1 shows, the overwhelming majority of participants rated their computer proficiency from Good $(33.9 \%)$ to Very Good $(58.3 \%)$. The study did not survey if the participants had training in ICT integration. Participants were from three subject areas: English, engineering, and medical science. They were recruited from several public universities in Saudi Arabia mainly through WhatsApp groups and email lists. There was no prerequisite for participating in the study. Even teachers who had no access to technology tools were able to participate.

Table 1. Participants' demographic information

\begin{tabular}{lll}
\hline & $\mathrm{N}$ & $\%$ \\
\hline Age & & \\
29 and younger & 6 & 3.3 \\
30-39 years & 118 & 65.6 \\
$40-49$ years & 31 & 25.9 \\
$50-59$ years & 25 & 17.2 \\
60 and older & 48 & 13.9 \\
& & \\
Years of teaching & & \\
5 or less & 36 & 20 \\
$6-10$ years & 41 & 22.8 \\
11-15 years & 36 & 20 \\
16 or more & 67 & 37.2 \\
& & \\
Computer skills & & \\
Poor & 1 & .6 \\
Moderate & 13 & 7.2 \\
Good & 61 & 33.9 \\
Very good & 105 & 58.3 \\
\hline
\end{tabular}

\subsection{Instruments}

Perceptions of readiness and beliefs about ICT, overall support, and technical support were measured using the Teacher Technology Questionnaire (Lowther et al., 2008) which is divided into two sections. The first section collects participants' demographic information (age, years of teaching experience) and computer proficiency. The second section collects teachers' level of agreement with 20 statements related to four variables: teacher readiness, teacher beliefs, teachers' perceptions of overall support and technical support. The questionnaire used a 5-point Likert scale: 5 "Strongly Agree"; 4 "Agree"; 3 "Neutral"; 2 "Disagree"; 1 "Strongly Disagree". The adopted instrument has been validated (Lowther \& Ross 2000; Sterbinsky \& Burke 2004) and is widely used in previous studies (e.g., Inan \& Lowther, 2010; Lowther et al., 2008; Corbeil \& Valdes-Corbeil, 2007; Grant, Ross, Wang \& Potter, 2005). The original version of the questionnaire was translated into Arabic by a professional translator who is a native speaker of Arabic. Both Arabic and English versions of the questionnaire were made available for participants since some of them had a low level of English while others could not read Arabic. The questionnaire was piloted with a group of instructors. Based on their comments and suggestions a few questionnaire items were revised. To examine the instrument's internal consistency, Cronbach's $\alpha$ was computed. The alpha value was .874 , indicating an acceptable level of internal consistency.

\subsection{Data Analysis}

To assess the effect of the teachers' sociobiographical variables (gender, age, computer proficiency, and years of 
teaching experience) simultaneously and determine their relative contribution to the predictions of ICT integration, multiple regression analysis was performed. Furthermore, in order to explore the relationships between teachers' subject areas (dependent variable) and factors of technology integration: teacher readiness, teacher beliefs, teachers' perceptions of overall support and technical support (independent variables), a one-way analysis of variance (ANOVA) was carried out.

\section{Results}

Research Question \#1: To what extent do sociobiographical variables (gender, age, computer proficiency, and years of teaching experience) predict teachers' perceptions of ICT integration?

To investigate the simultaneous effect of the background variables (gender, age, computer proficiency, and years of teaching experience) on the participants' ICT integration, multiple regression analysis was conducted. Results (see Table 2) show that the presented model is significant as there was a significant relationship between the background variables and ICT integration $\left(\mathrm{p}=.00 ; \mathrm{R}^{2}=0.087 ; \mathrm{R}=0.295\right)$. As shown in Table $6, \mathrm{R}^{2}$ was 0.87 , which means gender and computer skills combined to explain less than $1 \%$ of the variance of perceptions about ICT integration.

Among the predictor variables, computer skills had the highest relative impact on ICT integration with $t$ value of 2.848 , while gender had a lower impact with a $t$ value of 2.530. Years of a teaching experience and age were not found to be predictors of perceptions about ICT integration.

Table 2. Regression model for predicting ICT integration

\begin{tabular}{lllll}
\hline Variable & $\mathrm{B}$ & $\mathrm{Beta}$ & $\mathrm{T}$ & $\mathrm{P}$ \\
\hline Gender & 1.657 & .186 & $2.530^{* *}$ & .012 \\
Years of teaching experience & .261 & .070 & .811 (n.s.) & .418 \\
Age & -5.10 & -.090 & -2.33 (n.s.) & .381 \\
Computer skills & 1.402 & .213 & $2.848^{* *}$ & .005 \\
\hline
\end{tabular}

Model $\mathrm{R}=.295 ; \mathrm{R}^{2}=.087 ;$ Adjusted $\mathrm{R}^{2}=.066 ;$ Std. Error $=4.183 ; \mathrm{F}=4.143 ; \mathrm{p}=<.0005$

$* * \mathrm{p}<.0005$

Research Question \#2: To what extent are English Teachers' perceptions of technology integration different from their peers in engineering and medical science?

Table 3 reports the means and standard deviations for teachers' responses on each variable. Results of the one-way ANOVA showed no significant effect of subject area on perceptions about ICT integration (see Table 4). The analysis yielded no significant differences between groups (English, engineering, and medical science) on the readiness variable, $F(2,177)=.760, \mathrm{p}=.469$. Similarly, results of the one-way ANOVA on the teacher beliefs variable showed there was no significant effect, $F(2,177)=1.952, \mathrm{p}=.145$. With regard to the technical support variable, analysis showed no significant difference between teachers' responses for each group, $F(2,177)$ $=.220, \mathrm{p}=.802$. Furthermore, no significant difference was found between teachers' responses on overall technical support, $F(2,177)=.347, \mathrm{p}=.707$. These results suggest that teachers of English, engineering and medical sciences have the same responses regarding ICT integration. In other words, subject area has no influence on perceptions about ICT integration.

Table 3. Descriptive statistics on the four dependent variables

\begin{tabular}{|c|c|c|c|c|c|c|c|c|}
\hline & \multicolumn{2}{|c|}{ Teacher Readiness } & \multicolumn{2}{|c|}{$\begin{array}{l}\text { Teacher beliefs: } \\
\text { ICT impact on students } \\
\text { and classroom instruction }\end{array}$} & \multicolumn{2}{|c|}{$\begin{array}{l}\text { Teacher beliefs: ICT Overall } \\
\text { support learning }\end{array}$} & \multicolumn{2}{|c|}{$\begin{array}{l}\text { Teacher beliefs: ICTs } \\
\text { technical support }\end{array}$} \\
\hline & M & SD & M & $\mathrm{SD}$ & M & $\mathrm{SD}$ & M & SD \\
\hline English & 16.25 & 2.56 & 33.87 & 4.58 & 13.83 & 3.80 & 12.91 & 3.51 \\
\hline Engineering & 16.12 & 2.11 & 32.61 & 4.29 & 13.48 & 3.17 & 12.52 & 3.15 \\
\hline Medical & 15.73 & 2.02 & 34.81 & 3.52 & 14.16 & 3.08 & 12.98 & 2.86 \\
\hline
\end{tabular}


Table 4. One-way ANOVA of the four dependent variables

\begin{tabular}{|c|c|c|c|c|c|c|}
\hline & & $S S$ & $D f$ & $M S$ & $F$ & $P$ \\
\hline \multirow[t]{3}{*}{ Readiness } & Between Groups & .909 & 1 & .909 & .162 & .688 \\
\hline & Within Groups & 999.291 & 178 & 5.614 & & \\
\hline & Total & 1000.200 & 179 & & & \\
\hline \multirow{3}{*}{$\begin{array}{l}\text { ICT impact on students and } \\
\text { classroom instruction }\end{array}$} & Between Groups & 103.646 & 1 & 103.646 & 5.704 & .018 \\
\hline & Within Groups & 3234.548 & 178 & 18.172 & & \\
\hline & Total & 3338.194 & 179 & & & \\
\hline \multirow{3}{*}{$\begin{array}{l}\text { ICT impact on students and } \\
\text { classroom instruction }\end{array}$} & Between Groups & 22.974 & 1 & 22.974 & 2.137 & .146 \\
\hline & Within Groups & 1913.270 & 178 & 10.749 & & \\
\hline & Total & 1936.244 & 179 & & & \\
\hline \multirow[t]{3}{*}{ ICTs technical support } & Between Groups & 7.174 & 1 & 7.174 & .578 & .448 \\
\hline & Within Groups & 2208.471 & 178 & 12.407 & & \\
\hline & Total & 2215.644 & 179 & & & \\
\hline
\end{tabular}

\section{Discussion}

This section discusses each of the research questions addressed in this study. The first research question explored the impact of sociobiographical variables (gender, age, computer proficiency, and years of teaching experience) on teachers' perceptions of ICT integration. Results showed that gender and computer skills had an impact on teachers' perceptions of ICT integration while age and years of teaching experience had no impact. These outcomes echoed Inan and Lowther's study (2010) which has pointed to the effect of computer skills on ICT integration. However, unlike the current study, Inan and Lowther (2010) reported that years of teaching experience and age also had an effect on ICT integration. The findings of the current study could be explained by the fact that most of the participants are foreign teachers who have a similar profile in terms of competence regardless of age and years of teaching experience. In addition, the ability to integrate ICT in the classroom has recently been emphasized more than ever as one of the conditions for landing a teaching job at Saudi universities.

The second research questions addressed in this study examined whether English Teachers' perceptions of technology integration were different from their peers in engineering and medical science. Results showed that teachers of English, engineering and medical sciences have the same responses regarding ICT integration. In other words, subject area has no influence on perceptions about ICT integration. These findings suggest that subject areas (English, engineering and medical science) involved in this study are homogenous. This outcome is somewhat surprising since it contradicts numerous previous studies, which have reported that subject areas have an effect on ICT integration. Howard et al. (2014), for example, reported that on average, and over the course of three years, science teachers had a higher frequency of technology integration than their English peers. In an earlier study, Howard and Maton (2011), mathematics instructors reported a lesser tendency to use ICT in their teaching than English teachers. Similar outcomes were found by Tay et al. (2012), who reported that the frequency of ICT use was significantly lower in mathematics lessons than in English lessons.

The outcomes of this study have shown that English teachers hold the same strong beliefs about the impact of ICT on students and classroom instruction as their engineering and medical peers. The survey results show that English teachers perceived themselves as computer proficient as only one participant rated his computer skills as poor. This finding is rather positive since it suggests teachers are more likely to devise lesson plans that integrate technology (Pan \& Franklin, 2011). While being comfortable with using technology is crucial to ICT integration (Rakes, Fields, \& Cox, 2006) it should be combined with a solid pedagogical knowledge and the used technology for an effective integration of ICT in the classroom (Ertmer \& Ottenbreit-Leftwich, 2010). However, it raises the question related to the extent that teachers are able to effectively use technology beyond the drill and practice software or mere consultations of websites. The level of sophistication of technology use should be examined in future studies by observing teachers implement ICT integration in the classroom.

\section{Conclusion}

This study of a group of teachers in Saudi Arabia compared English language teachers' perceptions of ICT integration with their peers in engineering and medical science in ICT integration in tertiary teaching. It also explored the effects of teachers' sociobiographical variables (gender, age, computer proficiency, and years of teaching experience) on teachers' perceptions of ICT integration. The important findings are as follows: First, teachers of English shared the same perceptions of ICT integration with their peers in engineering and medical science. In other words, subject area played no role in ICT integration. Second, gender and computer skills had 
an impact on teachers' perceptions of ICT integration.

The findings reported in this study have some implications. First, ongoing opportunities for professional development must be provided to university teachers. Second, professional development should include effective technology training in order to develop teachers' understanding of the value of technology and effective uses in the classroom. Even though this study has not reported any role of study area in ICT integration, training programs should be designed for specific academic content. That will allow target teachers to appreciate the usefulness of technology. This study reports that gender had an impact on ICT integration. Therefore, technology training opportunities should be equally provided to male and female instructors.

There is one limitation to this present study. The research is based solely on teachers' responses to a questionnaire. Data collected from questionnaire has not been triangulated against the participants' interviews to ensure more reliable data. Teachers may have reported what they believed the researcher wanted to see regarding their integration of technology in the classroom. When participants are asked to report their own behavior their opinions may be biased (Greene, 2015). Therefore, the interpretations of findings reported in this paper may be limited. Despite this limitation, this study is one of the few to compare perceptions about technology integration among English teachers with their peers in the subject areas of engineering and medical science.

\section{Acknowledgments}

The author wishes to acknowledge the approval and the support of this research study by the grant no.6990-EAR-2017-1-7-F from the Deanship of Scientific Research at Northern Border University, Arar, K.S.A.

\section{References}

Barron, A. E., Orwig, G. W., Ivers, K. S., \& Lilavois, N. (2001). Technologies for education: A practical guide (4th ed.). Greenwood Village, CO: Libraries Unlimited.

Chamorro, M. G., \& Rey, L. (2013). Teachers' beliefs and the Integration of Technology in the EFL Class. HOW, A Colombian Journal for Teachers of English, 1(20), 51-72.

Corbeil, J. R., \& Valdes-Corbeil, M. E. (2007). Globalizing professional development: The evaluation of a collaborative computer-mediated professional development program. Issues in Information Systems, 8(2), 76-82.

Cuban, L. (1993) Computers Meet Classrooms: Classrooms Wins. Teachers College Record, 95, 185-210.

Cuban, L. (2001). Oversold and underused: Computers in the classroom. Cambridge, MA: Harvard University Press.

Cuban, L., Kirkpatrick, H., \& Peck, C. (2001). High access and low use of technologies in high school classrooms: explaining an apparent paradox. American Educational Research Journal, 38(4), 813-834. https://doi.org/10.3102/00028312038004813

Ertmer, P. A., \& Ottenbreit-Leftwich, A. (2010). Teacher technology change: How knowledge, confidence, beliefs, and culture intersect. Journal of Research on Technology in Education, 42(3), 255-284. https://doi.org/10.1080/15391523.2010.10782551

Grant, M., Ross, S. M., Wang, W., \& Potter, A. (2005). Computers on wheels: An alternative to 'each one has one'. British Journal of Educational Technology, 36(6), 1017-1034. https://doi.org/10.1111/j.1467-8535.2005.00571.x

Gray, L., Thomas, M., \& Lewis, L. (2010). Teachers' use of educational technology in US public Schools: 2009 (NCES 2010-040). Washington, DC: National Center for Education Statistics, Institute for Education Sciences, U.S. Department of Education. Retrieved from http://nces.ed.gov/pubs2010/2010040.pdf

Greene, B. A. (2015). Measuring cognitive engagement with self-report scales: Reflections from over 20 years of research. Educational Psychologist, 50(1), 14-30. https://doi.org/10.1080/00461520.2014.989230

Hew, K. F., \& Brush, T. (2007). Integrating technology into K-12 teaching and learning: Current knowledge gaps and recommendations for future research. Educational Technology Research and Development, 55(3), 223-252. https://doi.org/10.1007/s11423-006-9022-5

Howard, S. K., \& Maton, K. (2011). Theorising knowledge practices: a missing piece of the educational technology puzzle. Research in Learning Technology, 19(3), 191-206. https://doi.org/10.3402/rlt.v19i3.17109

Howard, S. K., Chan, A., \& Caputi, P. (2014). More than beliefs: Subject areas and teachers' integration of 
laptops in secondary teaching. British Journal of Educational Technology. Advance online publication.

Inan, F. A., \& Lowther, D. L. (2010). Factors affecting technology integration in K-12 classrooms: A path model. Educational Technology Research and Development, 58(2), 137-154. https://doi.org/10.1007/s11423-009-9132-y

Lowther, D. L., \& Ross, S. M. (2000). Teacher Technology Questionnaire (TTQ). Memphis, TN: Center for Research in Educational Policy, The University of Memphis.

Lowther, D. L., Inan, F. A., Strahl, J. D., \& Ross, S. M. (2008). Does technology integration “work” when key barriers are removed? Educational Media International, 45(3), 189-206. https://doi.org/10.1080/09523980802284317

McCulloch, A. W., Hollebrands, K., Lee, H., Harrison, T., \& Mutlu, A. (2018). Factors that influence secondary mathematics teachers' integration of technology in mathematics lessons. Computers \& Education, 123, 26-40. https://doi.org/10.1016/j.compedu.2018.04.008

Oxford Business Group. (2010). Saudi Arabian Educational Overview: Vital Roles, Productive Planning, Learning Lessons, New Development (pp. 254-68). THE REPORT. Saudi Arabia: Oxford Business Group.

Pan, S. C., \& Franklin, T. (2011). In-service teachers' self-efficacy, professional development, and Web 2.0 Tools for integration. New Horizons in Education, 59(3), 28-40.

Rakes, G. C., Fields, V. S., \& Cox, K. E. (2006). The influence of teachers' technology use on instructional practices. Journal of Research on Technology in Education, 38(1), 411-426. https://doi.org/10.1080/15391523.2006.10782467

Sandholtz, J. H., Ringstaff, C., \& Dwyer, D. (1997). Teaching with technology: Creating student-centered classrooms. New York: Teachers College Press.

Sheingold, K., \& Hadley, M. (1990) Accomplished Teachers: integrating computers into classroom practice. New York: Centre for Technology in Education.

Sterbinsky, A., \& Burke, D. (2004). Tennessee EdTech Accountability Model (TEAM) Reliability Study. Alexandria, VA: The CNA Corporation.

Tamim, R. M., Bernard, R. M., Borokhovski, E., Abrami, P. C., \& Schmid, R. F. (2011). What Forty Years of Research Says about the Impact of Technology on Learning: A Second-Order Meta-Analysis and Validation Study. Review of Educational Research, 81(1), 4-28. https://doi.org/10.3102/0034654310393361

Tay, L. Y., Lim, C. P., \& Lim, S. K. (2015). Differences in ICT usage across subject areas: Acase of an elementary school in Singapore. Journal of Educational Computing Research, 53(1), 75-94. https://doi.org/10.1177/0735633115585930

Vongkulluksn, V. W., Xie, K., \& Bowman, M. A. (2018). The role of value on teachers' internalization of external barriers and externalization of personal beliefs for classroom technology integration. Computers \& Education, 118, 70-81. https://doi.org/10.1016/j.compedu.2017.11.009

\section{Copyrights}

Copyright for this article is retained by the author, with first publication rights granted to the journal.

This is an open-access article distributed under the terms and conditions of the Creative Commons Attribution license (http://creativecommons.org/licenses/by/4.0/). 